\title{
Antifouling properties of oligo(lactose)-based self-assembled monolayers
}

Roni Nugraha, John A. Finlay, Sophie Hill, Timmy Fyrner, Wetra Yandi, Maureen E. Callow, James A. Callow and Thomas Ederth

\section{Linköping University Post Print}

\section{Tweet}

N.B.: When citing this work, cite the original article.

This is an electronic version of an article published in:

Roni Nugraha, John A. Finlay, Sophie Hill, Timmy Fyrner, Wetra Yandi, Maureen E. Callow, James A. Callow and Thomas Ederth, Antifouling properties of oligo(lactose)-based selfassembled monolayers, 2015, Biofouling (Print), (31), 1, 123-134.

Biofouling (Print) is available online at informaworldTM:

http://dx.doi.org/10.1080/08927014.2014.1001841

Copyright: Taylor \& Francis: STM, Behavioural Science and Public Health Titles http://www.tandf.co.uk/journals/default.asp

Postprint available at: Linköping University Electronic Press http://urn.kb.se/resolve?urn=urn:nbn:se:liu:diva-114588 


\section{ANTIFOULING PROPERTIES OF OLIGO(LACTOSE)-BASED SELF-ASSEMBLED MONOLAYERS}

Roni Nugraha ${ }^{1, *}$, John A. Finlay ${ }^{3, \dagger}$, Sophie Hill ${ }^{3}$, Timmy Fyrner ${ }^{2, \#}$, Wetra Yandi ${ }^{1}$, Maureen E. Callow $^{3}$, James A. Callow ${ }^{3}$, and Thomas Ederth ${ }^{1, \ddagger}$

${ }^{1}$ Division of Molecular Physics and ${ }^{2}$ Division of Chemistry, IFM, Linköping University, SE58183 Linköping, Sweden

${ }^{3}$ School of Biosciences, University of Birmingham, Edgbaston, Birmingham B15 2TT, UK.

Current addresses:

*Department of Aquatic Product Technology, Faculty of Fisheries and Marine Science, Bogor Agricultural University, Indonesia.

${ }^{\dagger}$ School of Marine Science and Technology, Newcastle University, Newcastle, UK.

\# Simpson Querrey Institute for BioNanotechnology, Northwestern University, Chicago, USA.

$¥$ Corresponding author, ted@ifm.liu.se.

Published in

Biofouling. 31(1), 123-134 (2015). DOI: 10.1080/08927014.2014.1001841. 


\begin{abstract}
The antifouling properties of oligo(lactose)-based self-assembled monolayers (SAMs), using four different proteins, zoospores of the green alga Ulva linza and cells of the diatom Navicula incerta, were investigated. The SAM-forming alkylthiols, which contained 1, 2 or 3 lactose units, showed significant variation in antifouling properties, with no differences in wettability. Non-specific adsorption of albumin and pepsin was low on all surfaces. Adsorption of lysozyme and fibrinogen decreased with increasing number of lactose units in the SAM, in agreement with the generally observed phenomenon that thicker hydrated layers provide higher barriers to protein adsorption. Settlement of spores of $U$. linza followed an opposite trend, being greater on the bulkier, more hydrated SAMs. These SAMs are more ordered for the larger saccharide units, and it is therefore hypothesized that the degree of order, and differences in crystallinity or stiffness between the surfaces, is an important parameter regulating spore settlement on these surfaces.
\end{abstract}

Keywords: marine biofouling, oligo(lactose), self-assembled monolayer, Ulva linza $a_{s}$ Navicula incerta, protein resistance. 


\section{Introduction}

Colonization of underwater surfaces by fouling organisms involves secretion of adhesive materials, a diverse array of biological 'glues', to provide both temporary and permanent adhesion. These bioadhesives are typically rich in polysaccharides and proteins. For example, extracellular polymeric substances (EPS) secreted by microorganisms contains polysaccharides, proteins, and nucleic acids, responsible for the cohesive forces that keep microorganisms aggregated together and attached to surfaces (Flemming and Wingender 2001). The adhesive secreted by motile spores (zoospores) of the fouling alga Ulva linza to facilitate permanent attachment to a substratum is a polydisperse, self-aggregating hydrophilic 'family' of glycoproteins (Callow and Callow 2006). The adhesive secreted by cells of raphid diatoms appears to be more complex with glycoproteins and carbohydrates involved (see review by Molino and Wetherbee (2008)). The initial attachment of cells is a reversible process requiring the secretion of glycoprotein mucilage strands, which allow adhered cells to move (glide) across the surface (Molino and Wetherbee 2008, Poulsen et al. 2014).

To work as an adhesive facilitating permanent attachment, the substance must be fluid in order to spread over or 'wet' the surface, but with sufficient interfacial tension to prevent dissolution in the water. Having wet the surface the adhesive must bond to that surface in a process that involves the exclusion of water molecules. Finally the adhesive must cure quickly to achieve the cohesive strength required to bond the organisms under turbulent conditions. In view of this, one strategy for achieving antifouling properties is to develop a surface that has a capability to prevent the displacement of bound water, and strong water hydration has been generally accepted as a fundamental requirement for good antifouling properties. The classical example in this regard is polyethylene glycol (PEG), which has been subject to detailed studies, and where fouling resistance mechanisms have been thoroughly explored and explained for both large molecular weight brushes (Jeon et al. 1991); oligo ethylene glycol (OEG)-terminated 
alkylthiol monolayers (Prime and Whitesides 1993, Wang et al. 2000), or in synthetic PEG/OEG-based hydrogels (Ekblad et al. 2008).

While PEG is used for antifouling purposes in biomedical applications, it is subject to chemical degradation, and is not useful for long-term purposes, or in the marine environment (Thome et al. 2012). As alternatives to PEG-based materials, which have potentially good antifouling properties and the capacity to resist biological attachment in aqueous environments, sugars, or saccharides, are of considerable interest. Saccharides serve many and different roles in nature, and specificity in biological function is obtained through huge compositional and structural variety. Sugars with a high ratio of hydroxyl groups per saccharide residue, provide efficient hydrogen bonding of surrounding water molecules. In addition, the structural variability of saccharides, their abundance in nature, in combination with progress in both carbohydrate synthetic chemistry and characterization in recent years, make sugars attractive both from a practical and applied perspective, and - as is the case in this work - as materials suitable for well-defined model surfaces for fundamental antifouling research. Previous studies aiming to explore antifouling properties of sugars include, for example, a study by Morra and Cassineli (1999) showing that highly hydrated hydrophilic polysaccharides could prevent mammalian cell adhesion and reduce bacterial adhesion. The non-charged natural polysaccharide dextran forms highly hydrated hydrogels which show very low non-specific interactions with proteins (Piehler et al. 1999). Luk et al. (2000) found a monosaccharide, mannitol-terminated alkylthiol, to be resistant to both protein adsorption and cell attachment. Molecular simulations showed that the protein-resistant properties of mannitol correlate well with its hydration capacity (Hower et al. 2008). The cell glycocalyx is rich in glycosylated molecules, and the high resistance of this hydrated structure toward nonspecific interactions is a source of inspiration for biomimetic antifouling materials. Ruegsegger and Marchant (2001) developed glycocalyx-like materials based on oligomaltose with ability to resist protein and 
platelet adhesion, and have been followed by others (Ham et al. 2013, Sen Gupta et al. 2006). In a marine biofouling context, Cao et al. (2009) used polysaccharide-based coatings based on hyaluronic acid, alginic acid and pectic acid. However, while these polyelectrolyte sugars were effective against proteins and animal cells, they were not suitable for marine environments due to complexation of bivalent ions and subsequent chain-chain association and hydrogel formation. In previous work, we have used neutral galactoside-terminated saccharide SAMs with varying degrees of methylation for antifouling studies using model proteins (Hederos et al. 2005) and marine organisms (Ederth et al. 2011). In the latter, it was demonstrated that the settlement and adhesion of several marine organisms onto the galactosides varied depending on the molecular structure of the SAMs. In particular, for surfaces with similar wettabilities and chemical functionalities, settlement (attachment) was dependent on the hydration structure at the interface. In a subsequent study the structure and antifouling capacities of a series of monoand oligosaccharide-terminated SAMs was explored (Fyrner et al. 2011), with the finding that molecular structure was affected by the bulkiness of the saccharide moieties, but in some cases it was also dependent on subtle details in the glucoside headgroups. Bulkier headgroups (e.g., $\alpha$-glucosidic bonds) reduce the structural qualities and increase disorder in both the headgroup and alkyl chain regions. Fibrinogen adsorption was low on the disordered SAMs, while settlement of zoospores of $U$. linza and barnacle cypris larvae was low overall. However, it was also demonstrated recently that large intermolecular interactions between relatively rigid saccharide moieties can instead improve the molecular order for longer oligosaccharides, as is the case in a series of oligo(lactose)-based thiol SAMs (Fyrner et al. 2013).

In the present study, the antifouling properties of these oligo(lactose)-based thiol SAMs, were investigated with a view to clarifying the relationship between surface hydration, SAM molecular structure and antifouling performance. For the antifouling studies, a series of model proteins, settlement and adhesion assays of zoospores of the green alga $U$. linza, and cells of 
the diatom (microalga) $N$. incerta were used. Resistance to non-specific protein adsorption may be considered to be a general indication of surface inertness, but its use here is also related to potential biomedical applications, as well as a means to explore the relevance of protein adsorption tests as predictors of marine antifouling properties. $U$. linza is a major macrofouling alga which colonizes surfaces through the production of vast quantities of microscopic motile spores (Callow and Callow 2006), while diatoms are interesting microfoulers in that they frequently succeed in fouling submerged artificial surfaces, and produce thick slime even on biocidal antifouling paints, and also adhere tenaciously to fouling-release coatings based on silicone elastomers (Zargiel et al. 2011, Zargiel and Swain 2014). Three oligo(lactose) thiols, forming di-, tetra- and hexasaccharides (containing 1, 2, and 3 lactoside groups, respectively, see Figure 1), were investigated. Two standards were used; maltotrioside, which has proven effective against fouling in previous studies (Fyrner et al. 2011), and a methoxylatedoligoethylene glycol, representing another surface known to possess good antifouling properties (Figure 1).

\section{Materials and methods}

\section{Self-Assembled Monolayer preparation}

Three oligo(lactosides) glycosylated in a $(1 \rightarrow 3)$ manner and functionalized with amide-linked short alkanethiol spacers, forming di-, tetra-, and hexasaccharides with one (Lac1), two (Lac2), or three (Lac3) lactose units, were prepared and characterized as described in Fyrner et al. (2013). The synthesis of the maltotrioside (Mal-tri) is described in Fyrner et al. (2011). The methoxy-OEG alkylthiol (HS- $\left.\left(\mathrm{CH}_{2}\right)_{10}-\mathrm{CONH}-\left(\left(\mathrm{CH}_{2}\right)_{2} \mathrm{O}\right)_{11}-\mathrm{CH}_{3}\right)($ mOEG) was obtained from Polypure (Oslo, Norway), and used as received. 
Cleanroom-cleaned $76 \times 25 \mathrm{~mm}^{2}$ Nexterion Glass B slides (Schott) and Silicon (100) wafers with native oxide (cut into pieces, $12.5 \times 12.5 \mathrm{~mm}^{2}$ for protein adsorption experiment or $20 \times$ $40 \mathrm{~mm}^{2}$ for IRAS) were prepared as SAM supports. The Nexterion Glass B slides were used as received, while Silicon wafers were TL1-cleaned $\left(5 / 7 \mathrm{H}_{2} \mathrm{O}, 1 / 730 \% \mathrm{H}_{2} \mathrm{O}_{2}\right.$, and $1 / 725 \% \mathrm{NH}_{3}$ at $80{ }^{\circ} \mathrm{C}$ for $10 \mathrm{~min}$ ) before metal deposition. A custom-built electron-beam vacuum evaporation system with a base pressure of less than $3 \times 10^{-6}$ Torr was used to coat the substrates with a $25 \AA$ titanium adhesion layer at a rate of $0.3-0.5 \AA / \mathrm{s}$ and an additional $300 \AA$ (at $5 \AA / \mathrm{s}$ ) gold layer for Nexterion Glass slides, or $2000 \AA$ (at $10 \AA / s$ ) for silicon wafers. The substrates were TL1-cleaned twice prior to thiol incubation. SAMs were self-assembled from $50 \mu \mathrm{M}$ solutions of the thiols in water (Lac1-3) or ethanol (all other thiols). After $24 \mathrm{~h}$ incubation, the substrates were rinsed with $99.5 \%$ ethanol, sonicated for 2 min in ethanol to remove any physisorbed thiols, and then gently dried in an $\mathrm{N}_{2}$ stream. Nexterion Glass slides with SAMs for bioassays were packed and sealed under $\mathrm{N}_{2}$ immediately after preparation, while silicon wafers with deposited SAMs were analyzed immediately using ellipsometry, contact angle goniometry and infrared spectroscopy.

\section{Ellipsometry}

SAM and adsorbed protein layer thicknesses were measured using a Rudolph Research AutoEL ellipsometer with $70^{\circ}$ angle of incidence and a He-Ne laser $(\lambda=632.8 \mathrm{~nm})$ as a light source. A three-phase substrate/organic film/air model with refractive index of 1.5 for the organic layer was used to calculate thicknesses, assuming isotropic and transparent organic layers. Data from five different spots on each sample were automatically acquired and averaged, and at least three different samples were compared to ensure consistency. For SAM thickness determination, the optical characteristics of the gold substrates were obtained after TL1 cleaning. For protein layer 
thicknesses, the optical properties of the gold layer with the adsorbed SAMs were used as the substrate in the model.

\section{Contact Angle Goniometry}

The advancing and receding water contact angles on SAMs were determined using a semiautomatic optical contact angle meter (KSV CAM 200). Sessile droplets were manually expanded or contracted using a syringe, and contact angles were determined from edge analysis of images recorded of the droplets during expansion or contraction, using the software supplied with the instrument. Data for each SAM were obtained from averaging two samples, two measurements were made on each sample, and each measurement consisted of at least ten images for the advancing and receding angles respectively.

\section{Infrared reflection-absorption spectroscopy (IRAS)}

Fourier-transform infrared reflection-absorption spectroscopy measurements were performed on a Bruker IFS66 spectrometer system using a grazing angle $\left(85^{\circ}\right)$ reflection setup, equipped with $\mathrm{LN}_{2}$ cooled MCT detector and continuous $\mathrm{N}_{2}$ purging. All spectra were acquired at $2 \mathrm{~cm}^{-1}$ resolution between 4000 and $700 \mathrm{~cm}^{-1}$, as a summation of 3000 scans. A three-term BlackmannHarris apodization was applied to the interferograms before Fourier transformation. Background spectra were acquired using a deuterated hexadecanethiol SAM.

\section{Protein Adsorption Experiment}

Protein solutions $(1 \mathrm{mg} / \mathrm{mL})$ were prepared from the respective protein in PBS (10 $\mathrm{mM}$ sodium hydrogen phosphate $\mathrm{Na}_{2} \mathrm{HPO}_{4}, 10 \mathrm{mM}$ potassium dihydrogen phosphate $\mathrm{KH}_{2} \mathrm{PO}_{4}$, and $150 \mathrm{mM}$ 
$\mathrm{NaCl}$ in water). Prior to incubation in protein solutions, the SAMs were rinsed with water and gently dried with $\mathrm{N}_{2}$, and the SAM thickness was determined by ellipsometry. The SAMs were incubated in $4 \mathrm{~mL}$ protein solution for $30 \mathrm{~min}$ at room temperature. Samples were then transferred into glass beakers filled with PBS. After 10 min, the samples were rinsed with water; dried with nitrogen and the thickness measured with ellipsometry, following the previously described procedure. The amount of adsorbed protein was obtained from the thickness increments of the organic layers on the samples. Three independent experiments were carried out with similar results, and data from one of these is shown in the following (data for three fibrinogen assays is included). The results were evaluated using nested ANOVA with pairwise Tukey comparison.

\section{Ulva linza assay}

Fertile thalli of the green macroalga $U$. linza were collected from Llantwit Major beach, Glamorgan, Wales $\left(52^{\circ} 23^{\prime} \mathrm{N}, 3^{\circ} 30^{\prime} \mathrm{W}\right)$. Fertile tips were cut and put into artificial seawater (ASW) at $\mathrm{pH} 8.0$ and 32\%o to release zoospores. The zoospores were prepared for settlement assays following a previously described method (Callow et al. 1997). The package containing SAM-coated samples package was opened immediately prior to the assay, and one slide was placed in a separate compartment of a Quadriperm dish (Greiner BioOne Ltd.). Detailed procedures for assays are provided in (Callow et al. 1997) and (Thome et al. 2012). In brief, 10 $\mathrm{mL}$ of a suspension containing $1.5 \times 10^{6}$ zoospores were added to six replicates of each surface. After 45 min incubation in darkness, the slides were gently washed by moving up and down 10 times in a beaker of seawater. Three replicates were fixed in glutaraldehyde in seawater $(2.5 \%$ $\mathrm{v} / \mathrm{v}$ ) for $20 \mathrm{~min}$, washed in deionised water to remove salts and air-dried. The other three replicates were exposed to a wall shear stress of $52 \mathrm{~Pa}$ in a water channel (Schultz et al. 2000) 
and then fixed as described above. Glass standards were used to monitor normal settlement of the spores. The density of adhered spores was determined by fluorescence of chlorophylla as described in Callow et al. (2002), using a Zeiss epifluorescence microscope with a $\times 20$ objective (excitation $546 \mathrm{~nm}$, emission $590 \mathrm{~nm}$ ), a video camera and a Zeiss Axiovision 4 image analysis system. Thirty fields of view were counted at $1 \mathrm{~mm}$ intervals along the length of each of 3 replicate slides before and after exposure in a flow channel. Zoospore removal data are expressed as a percentage of the initial density (i.e., before exposure to flow) of attached spores. A nested ANOVA with pairwise Tukey comparison was performed in Minitab 14. N = 90 throughout.

\section{Navicula incerta assay}

SAMs were prepared as described above for the zoospore settlement assay. Cells of $N$. incerta

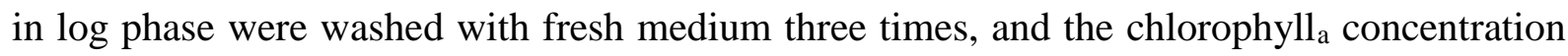
was adjusted to $0.25 \mu \mathrm{g} / \mathrm{mL}^{-1}$ (Finlay et al. 2010). Ten milliliters of the cell suspension were added to compartments of Quadriperm dishes, each containing a slide and allowed to settle for $2 \mathrm{~h}$ before the slides were rinsed with ASW to remove cells that had not adhered to the surface. Three replicates were fixed with $2.5 \%$ glutaraldehyde in ASW, and the other three replicates were exposed to a shear stress of $32 \mathrm{~Pa}$ in a calibrated water channel in order to determine the adhesion strength of the cells. The number of cells on the samples was counted, and percent removal was calculated as described for spores of $U$. linza. 


\section{Results}

\section{SAM Characterization}

The SAMs were prepared on either $30 \mathrm{~nm}$ gold films deposited onto Nexterion glass slides (for algal assays) or $200 \mathrm{~nm}$ gold films on silicon (100) wafers (for IRAS, ellipsometric and wettability characterization and protein adsorption experiments). Results of ellipsometry and contact angle measurements are summarized in Table 1. The structure of the monolayers, in particular the molecular orientation and the order of the monolayers, were characterized by IRAS, with the results presented in Figure 2. Free OH-groups absorb in narrow bands typically found in the range $3650-3600 \mathrm{~cm}^{-1}$ (sharp bands at 3657 and $3756 \mathrm{~cm}^{-1}$ for water), which are broadened by hydrogen-bonding to $3600-3000 \mathrm{~cm}^{-1}$ in polar solvents or condensed phases. The IRAS data in Figure 2a show contributions in this $\mathrm{O}-\mathrm{H}$-stretching region for all samples. The saccharides Lac1-3 and Mal-Tri have contributions from both saccharide hydroxyl groups and hydration water. Although the IRAS experiments were conducted under "dry" nitrogen-purging conditions, this purging does not remove all water from hydrophilic materials. This is also clear from the mOEG spectrum; this molecule does not have any OH-groups, but still a substantial intensity in this region (potentially overlapping amide N-H stretching would not cover the whole band, and also be largely suppressed by the surface selection rule, saying that vibrations with their transition dipole moments parallel to the metal substrate are invisible in IRAS, see below). Strongly coordinated ("icelike") water would absorb predominantly in a broad band centered around $3230 \mathrm{~cm}^{-1}$, and water with lower coordination ("liquidlike") near $3400 \mathrm{~cm}^{-1}$ (Du et al. 1994, Kim and Cremer 2000). It appears from the figure that all SAMs have contributions in both these regions, but with varying relative intensities. In the $\mathrm{CH}$-stretching region (2800-3000 $\mathrm{cm}^{-1}$ ), the position of the symmetric and asymmetric $\mathrm{CH}_{2}$ modes are sensitive probes of chain order and orientation, and occur at 2850 and $2918 \mathrm{~cm}^{-1}$ in crystalline all-trans chains, but shift to higher frequencies upon introduction of gauche defects or disorder. 
The Mal-Tri spectrum, with peaks at 2852 and $2922 \mathrm{~cm}^{-1}$ indicate a somewhat disordered, but still predominantly crystalline, alkane layer. The short alkyl spacers in the Lac1-3 SAMs form a thin but disordered alkane layer with peaks shifted toward higher frequencies, and the difference in relative contribution of the two peaks, compared to that of Mal-Tri, indicate also a different orientation of the spacer chains. The CH-band in mOEG can be deconvoluted into several components, the positions of the most significant contributions are indicated in Figure 2a. Bands at 2864 and $2922 \mathrm{~cm}^{-1}$ originate from the alkyl chain, the former possibly shifted to higher frequencies from overlap by symmetric $\mathrm{CH}_{3}$ stretching, which is expected in this region, but cannot be resolved as a separate band. The intense peak at $2891 \mathrm{~cm}^{-1}$ is a contribution from $\mathrm{CH}_{2}$ stretching in the OEG methylenes, and characteristic of crystalline helical OEG (Valiokas et al. 2000). Figure $2 \mathrm{~b}$ shows the fingerprint region of the SAM spectra. The saccharides have strongly suppressed Amide I bands $\left(1650-1660 \mathrm{~cm}^{-1}\right)$, indicating that the amide carbonyl is oriented parallel to the metal substrate (Fyrner et al. 2013), and is thus invisible according to the surface selection rule. This is even more pronounced in mOEG, where complete removal of the Amide I band also is consistent with very weak N-H stretching (as discussed above), since both the amide carbonyl and the N-H stretch have similarly oriented transition dipole moments. For the saccharides, weak bands from 1500 to $1200 \mathrm{~cm}^{-1}$ reflect a large number of overlapping saccharide and $\mathrm{CH}_{2}$ bending vibrations, and peaks at $1200-950 \mathrm{~cm}^{-1}$ include $\mathrm{C}-\mathrm{O}$, C-C, C-C-H, and C-O-C skeletal modes. The positions and relative intensities of these depend on saccharide structure and local environment and, due to the surface selection rule in IRAS, also on their orientation, making further interpretation difficult. However, the similarity in band shape, with variation only in intensity between the Lac1-3 SAMs indicates that the orientation of the lactose groups is similar in the three cases, and that the intensity variations are an effect of the increasing number of saccharide units. The mOEG spectrum displays a series of bands which are unique to helical crystalline OEG phases, the most prominent are the $\mathrm{CH}_{2}$ modes at 
1461 (scissor), 1349 (wag), 1244 (twist), and $964 \mathrm{~cm}^{-1}$ (rock), as well as the skeletal C-O-C stretching at $1116 \mathrm{~cm}^{-1}$ (Valiokas et al. 2000). The latter peak overlaps with a smaller contribution from upright all-trans $\mathrm{OEG}$ at $1144 \mathrm{~cm}^{-1}$, and integration of the deconvoluted band gives a ratio of 3:1 for the two peak areas. The results in Table 1 and the IRAS spectra are in good agreement with the results obtained in previous, detailed studies on these SAMs (Fyrner et al. 2013, Fyrner et al. 2011).

\section{Protein Adsorption}

The ability of a surface coating to prevent non-specific protein adsorption is commonly used to test antifouling properties. Here, the SAMs were tested against four proteins chosen to cover a range of sizes from 14 to $340 \mathrm{kDa}$, (lysozyme and fibrinogen respectively); globular versus non globular proteins (BSA and fibrinogen respectively), and surface charge properties from the $\mathrm{pI}$ 2.9 of pepsin to $\mathrm{pI} 11$ for lysozyme (Table 2). Protein adsorption tests were conducted as ellipsometric thickness increment tests after incubation. Of the four proteins tested, fibrinogen and lysozyme were found to adsorb in significant amounts to the tested surfaces, but with little or no adsorption of albumin and pepsin (Figure 3). The ability of the Mal-tri surface to prevent protein adsorption has been discussed in a previous paper (Fyrner et al. 2011). A control experiment with samples incubated in PBS, but without any protein, resulted in a $1 \AA$ thickness decrease for Lac1-2, and $2.5 \AA$ decrease for the Lac3 samples. The extent of fibrinogen and lysozyme adsorption differed significantly with the surface coating (ANOVA, $p<0.01$ ) The amount of adsorbed fibrinogen on Lac1 was significantly higher than that on Lac2, Lac3, and Mal-tri (Tukey's test, $\mathrm{p}<0.01$ ), but not different from that on mOEG. Fibrinogen adsorption onto Lac2, Lac3, and Mal-tri were statistically indistinguishable (Tukey's test, p > 0.05). 
Lysozyme adsorption onto Lac1 was significantly higher than that on Lac2 and Lac3 (Tukey's test, $\mathrm{p}<0.01$ ), but differences between the latter two were non-significant.

\section{Ulva linza zoospore settlement and adhesion strength assays}

The assay was conducted twice with different batches of spores with similar results, data from one of these assays is shown in Figure 4. Substantial differences in zoospore settlement were found on the saccharide surfaces, with the lowest settlement density found on Lac1 and the highest on Lac3 (Figure 4). One-way nested ANOVA analysis shows that the attachment density differed significantly with surface type ( $\mathrm{p}<0.01)$. Tukey's pairwise comparison shows that, with the exception of Mal-tri and mOEG, which were indistinguishable, the settlement densities on all samples were significantly different from each other, $(\mathrm{p}<0.01)$.

Exposure of samples with settled spores to shear stress in the flow channel, as a measure of adhesion strength, significantly reduced the density of settled spores only on surfaces Lac3 and Mal-tri with 30\% and 72\% removal, respectively (Figure 4). For the other samples the number of spores before and after the flow channel exposure did not differ significantly. It should also be noted that for Lac1, the small number of initially settled spores means that \% removal values must be treated with caution.

\section{Attachment of Navicula incerta}

Diatoms, such as $N$. incerta, are microfouling algae, which reach a surface by gravity or water currents, rather than motility in the water column. Thus, at the end of a $2 \mathrm{~h}$ incubation period, the same density of cells is in contact with all surfaces. Non-attached cells on the surfaces are 
readily removed by gentle washing, thus any difference in the remaining cell density reflects differences in their ability to adhere. The initial density of diatom cells was similar on all surfaces except mOEG (Figure 5), which had a lower attachment density. The applied hydrodynamic stress removed the majority of the cells from all of the surfaces except for Lac1 with only $32 \%$ removal (Figure 5). The assay was conducted twice with similar results, and Figure 5 shows the result of one of these assays.

\section{Discussion}

\section{SAM structure}

The SAM characterization by ellipsometry, wetting and IRAS was conducted to ensure the quality and the consistency of the SAMs. The results overall were in good agreement with data presented in previous studies of Lac1-3 (Fyrner et al. 2013), Mal-tri (Fyrner et al. 2011) and of OEG-terminated SAMs (Valiokas et al. 1999, Valiokas et al. 2000). For the three SAMs Lac1-3, it is concluded from both the thicknesses and the IRAS data (showing that the amide carbonyl bonds are parallel to the surface), that the monolayers all formed with the hydrocarbon spacers in a near-upright conformation, and that the orientation of the sugar moieties were similar in all cases. The larger increase in thickness between Lac2 and Lac3, than that observed between Lac1 and Lac2, also accompanied by a greater increase in the integrated IR fingerprint region intensity in the former case (integration over the interval $1180-950 \mathrm{~cm}^{-1}$ in Figure $2 \mathrm{~b}$ gives the areas $0.43: 0.64: 1$ for Lac1-3, if normalized to the intensity of Lac3), indicate an additional ordering and higher packing density for longer oligomers due to stronger intermolecular interactions between the rigid and rod-like oligo(lactoses) (Fyrner et al. 2013), much as is observed for plain alkanethiols with alkyl 
chains longer than about 10 methylene units (Porter et al. 1987). This is opposite to the behaviour for $\alpha$-oligo(glucose) SAMs, where increasing the number of glucose units from one to three (Mal-Tri ) results in increasingly disordered SAMs, and where the layer thickness does not increase significantly between SAMs with two and three glucose units (Fyrner et al. 2011). Thus, while the Lac1-3 form a series of SAMs with increasing order, the Mal-Tri self-assembles into layers with considerable disorder in the saccharide region. Long alkyl chains typically promote the formation of organized layers in functionalized alkylthiols, but for the oligo(glucose) Mal-tri this does not occur; for Lac1-3 this evidently is not required. This structural difference between oligo(lactose) and oligo(glucose) SAMs is related to the structure and packing in the saccharide moieties. The linear conformation in lactose units is due to the $\beta(1 \rightarrow 4)$ linkage, making a compact assembly possible (Aripin et al. 2012, von Minden et al. 2000), in contrast to Mal-Tri with $\alpha(1 \rightarrow 4)$ linkage. Further, the $\beta(1 \rightarrow 3)$ glycosidic bonds between the lactose units, leaving a free axial hydroxyl group at the galactose C4, favours hydrogen bonding which stabilizes the assembly (Aripin et al. 2012).

The IRAS result for the mOEG SAM has the distinctive characteristics of vertically oriented, crystalline and helical OEG chains, with some contribution also from all-trans chains, on top of the alkyl chain layer. The helical structure is also consistent with the predominance of "ice-like" water on the mOEG, due to the strong capacity of helical OEG chains to coordinate water (Wang et al. 2000), The highly organized OEG chains exposing a terminating methoxy group is also a likely explanation for the high water contact angles observed on these SAMs (Table 1), but the very low contact angle hysteresis also indicates that the SAMs are wellordered and densely packed, with little room for reorganization upon exposure to water. While organized OEG layers could potentially form less protein resistant layers than those of shorter, and disordered OEG segments (see below), the (EG) 11 -terminated thiol mOEG was selected since it forms layers of similar thickness as Lac3 and Mal-tri. 


\section{Fouling assays}

The negative thickness differences observed for some sample-protein combinations in Figure 3 were also seen in control experiments conducted in PBS without proteins, but the negative values in the protein assays are not fully accounted for by the 1-2.5 $\AA$ negative thickness changes observed in PBS. Desorption from the SAM could contribute to the negative thicknesses observed in a few cases in Figure 3. Desorption in water is expected to be somewhat greater from the Lac1-3 SAMs than for Mal-tri, due to the longer hydrocarbon chain in the latter, which provides additional stability, but Mal-tri has a greater negative value than any of the Lac samples, despite its better stability, making desorption an unlikely explanation for the negative values. There remains a possibility that e.g. impurities in the protein solutions cause partial collapse of the layers, or that physisorbed material is removed by surface-active impurities in the protein solutions but not by PBS. However, triplicate independent experiments - Figure 3 shows the result of one of these -showed a similar trend of decreasing fibrinogen and lysozyme adsorption for the longer Lac samples, and for this reason we consider this trend reproducible.

The high adsorption of fibrinogen on mOEG might appear unexpected, considering the welldocumented protein resistance of OEG SAMs (Prime and Whitesides 1993). However, a reduction of the protein resistance of the highly organized mOEG SAMs, exposing methyl groups, is in good agreement with previous systematic studies (Herrwerth et al. 2003). It is also observed that details of the conformation of the OEG moiety in such monolayers can have dramatic effects on the protein resistance (Harder et al. 1998, Riepl et al. 2005). Considering that the mOEG SAMs performed well in both the $U$. linza and the $N$. incerta assays, in that cell attachment densities were low, we attribute the fibrinogen adsorption result to such 
conformational effects, but also note that the different environments that were necessary for the protein (PBS) and the marine fouling assays (ASW) could potentially also contribute to differences in antifouling performance.

It is interesting that the fibrinogen and lysozyme protein adsorption tests, as well as the $U$. linza spore settlement and release assays and the diatom release assays show significant differences in the performance of Lac1, Lac2 and Lac3. The most striking results are the clear and opposite trends of protein adsorption and spore settlement in the series Lac1 $\rightarrow \mathbf{3}$. The opposite trends of spore settlement and fibrinogen adsorption are inconsistent with findings on various OEGterminated SAMs of differing wettability (Schilp et al. 2007) or different chain lengths (Schilp et al. 2009), where these were observed to correlate positively with each other. Further, a positive correlation between $U$. linza spore settlement density and surface hydrophobicity (high water contact angle) has also been established through other studies, for example on hydroxyland methyl-terminated SAMs (Callow et al. 2000), or xerogels (Bennett et al. 2009). In the present case the differences in wettability between the Lac1-3 SAMs are too small to explain the considerable variations in either spore settlement or spore removal. To explain the observed trends for Lac1-3, two other surface properties that might possibly influence spore settlement: surface hydration and molecular order, should be considered.

\section{Surface hydration}

Integration of the O-H-stretching bands for Lac1-3 in the range $3580-3050 \mathrm{~cm}^{-1}$ shows that the intensities in the three Lac SAMs were proportional to the thicknesses of the layers (see Figure 6), and the shape of the bands are very similar, confirming that hydration was similar on all saccharide units, and thus also throughout the thickness of the Lac1-3 monolayers.. The 
hydrogen-bonded O-H stretching bands in the IR spectra of Lac1-3 were dominated by lowcoordinated "liquidlike" water molecules (absorption maximum near $3400 \mathrm{~cm}^{-1}$, see Figure 2a), in agreement with the observations for highly hydroxylated galactoside monosaccharide SAMs (Ederth et al. 2011). However, there were also significant contributions from strongly coordinated "icelike" water (tetrahedral coordination, absorption around $3230 \mathrm{~cm}^{-1}$ ) in all three lactose-based SAMs. The relative contribution of the latter band decreased slightly with increasing number of lactose units (quantification by deconvolution of the two bands is difficult because water and saccharide $\mathrm{O}-\mathrm{H}$ contributions cannot be separated). This change might indicate either a slightly different hydration structure at the additional lactose units for Lac2 and Lac3, or alternatively, that the hydration of the whole molecule is slightly different due to the different packing of the chains in the Lac2 and Lac3 monolayers. If the differences in total intensity of the $\mathrm{O}-\mathrm{H}$-stretching bands are translated into equal differences in the number of hydrogen-bonded water molecules, the enthalpic cost of replacing the bound water by other molecules is greater on Lac 3 than on Lac 2 or Lac 1, which could explain the observed differences in protein adsorption. This would be just as expected from a wealth of previous results, ranging from early work on PEG brushes (Jeon et al. 1991) and OEG conformers (Wang et al. 2000) to more recent results from protein adsorption onto oligomaltose surfactant polymers, showing positive correlation between protein resistance and the increasing depth of the oligomaltose layer (Ruegsegger and Marchant 2001). This, of course does not clarify the opposite trend observed in the $U$. linza spore assay.

\section{Molecular order}


In previous work, we observed that fibrinogen adsorption was lower on di- and tri-saccharides than on monosaccharides (Fyrner et al. 2011). This could be because longer-chain molecules have a better coverage of the substrate, and thereby prevent attachment of proteins (Prime and Whitesides 1993) though the structural data in that particular case makes penetration through the SAM to the substrate unlikely. In addition, more saccharide units per chain means more hydrated water to remove for an approaching protein, which is a reasonable explanation for higher protein resistance. However, the layer thicknesses (and thus also hydration water content) were relatively similar for mono-, di- and tri-saccharides, and the data therefore pointed instead to the increasing layer disorder as the reason for more effective antifouling behaviour in the longer saccharides (Fyrner et al. 2011). Oligosaccharides with bulky headgroups, such as Mal-tri form disordered monolayers with better antifouling properties compared to, for example, more crystalline-like monosaccharide-terminated SAMs (Fyrner et al. 2011). The excellent protein resistance of grafted PEG is usually attributed to steric repulsion from the flexible PEG chains, caused by osmotic stress and entropy loss upon compression, and with protein resistance increasing with the grafting density and chain length (Jeon et al. 1991). While similar effects might contribute to the improved protein resistance of oligo(glucose) SAMs, such as Mal-Tri, which are disordered and flexible, the chains in the Lac1-3 SAMs do not have the configurational freedom to allow such a mechanism to operate. Similar to PEG brushes, resistance to protein adsorption (Pasche et al. 2003), bacterial attachment (Ista and López 2012), and algal cell settlement (Schilp et al. 2009) onto short-chain EG-terminated SAMs decrease with the increasing surface density of EG units, and while the mechanism in operation here must be different from that of PEG brushes, it still cannot account for the increased fouling with layer thickness for $U$. linza settlement onto Lac1-3. In contrast to Maltri and its analogs, the oligo(lactose)-based SAMs Lac1-3 show an increase in molecular order and chain packing with increasing number of saccharide units, and associated with that a 
decrease in protein adsorption and an increase in zoospore settlement. There remains a possibility that the interaction between the spore and the SAM has a specific contribution, but as is always the situation with SAMs, steric availability of the lactose moieties is expected to be poor, due to the embedding of the lactose units in a relatively well-ordered layer. Spores of U. linza are motile; with the aid of flagella they have the ability to locate and explore a suitable substrate for attachment, and they also detect and respond to mechanical stimuli (thigmotaxis) (Callow and Callow 2011). It may therefore be hypothesized that the increasing surface order, and thus increasing crystallinity or stiffness of the layer, is the reason for the increased spore settlement for the longer Lac chains, with the caveat that the observed differences in settlement are surprisingly large for the expected variations in surface structure of the Lac1-3 SAMs.

\section{Adhesion strength of $\mathrm{U}$. linza and $\mathrm{N}$. incerta}

The shear stresses in the adhesion assays were chosen to allow effective discrimination between test surfaces, bearing in mind the different adhesion strengths of the test organisms. Since diatoms adhere less strongly than Ulva, a somewhat lower shear stress is used for the former. Measurements of the detachment strength of algae in laboratory assays using the turbulent channel, at these operating pressures, provide a good indicator of the conditions necessary for detachment of such organisms in a turbulent boundary layer at ship scale (Schultz et al. 2003). Thus, wall shear stresses of 32 and $52 \mathrm{~Pa}$ are equivalent to the shear stresses experienced $50 \mathrm{~m}$ downstream from the bow of a ship moving with velocities of 13 and 17 knots, respectively. In the $U$. linza assay, there was significant removal of spores from Lac3, but spore densities before and after exposure to shear stress were not significantly different for Lac1 or Lac2. The $N$. incerta assay showed a trend of lower attachment strength and greater percentage removal from

Lac3 than from Lac1. Attachment strengths for both organisms have been coupled to substrate 
wettability in a number of studies, but usually with a trend in the opposite direction between the two species. While for diatoms, adhesion was seen to be lower on hydrophilic surfaces (Finlay et al. 2010, Finlay et al. 2013, Schilp et al. 2007), the general picture is that the removal of settled spores of $U$. linza in a flow channel followed a clear trend of lower adhesion (i.e. increasing removal) on hydrophobic surfaces (Finlay et al. 2002). Where this applies, thermodynamic models using interfacial free energies could be used to predict adhesive failure at the interfaces. However, wettability is again insufficient to explain the outcome of the removal assays, which might instead be understood in terms of the degree of order within the SAMs. Bowen et al. (2007) studied spore and diatom adhesion in relation to the chain lengths of SAMs formed from alkane thiols. Short-chain thiols (less than approx. 12 methylene units) were disordered, and crystallinity was markedly increased for longer chain length SAMs, which was associated with a clear decrease in adhesion strength of both Ulva and Navicula. The difference in adhesion between disordered (short chains) and crystalline (long chains) SAMs was ascribed to higher dissipation of shear stress through the disordered surfaces, and a smaller disruption of the adhesive bond between the organism and the SAM, and thus the adhesive bond fails more readily for longer alkyl chain lengths forming crystalline surfaces. This trend of higher removal from more ordered SAMs is in qualitative agreement with the observed behaviour for the organisms attached to the Lac1-3 surfaces. This is most evident in the Navicula assay, where removal increases from $35 \%$ for the disordered Lac1 to $75 \%$ for the more ordered Lac3. For Ulva, removal was only significant for Lac3, while there was no significant removal from Lac1 and Lac2. It is unclear how removal data for Mal-Tri, which is relatively high in both cases, fits into this scheme, but since there is no removal data available for the related series of SAMs in previous work, and the Mal-tri is different from the Lac1-3 series of SAMs in several respects, we refrain from speculating about the reason for this. 


\section{Conclusions}

We have investigated the antifouling properties of three oligo(lactose)-based SAMs against model proteins, zoospores of the green alga Ulva linza and cells of the diatom Navicula incerta. The length of the saccharide chain, i.e. the presence of 1,2 or 3 lactose units, has been shown to have significant effects on the antifouling properties of these SAMs surfaces, whilst having negligible effects on wettability. Non-specific protein adsorption to the different surfaces decreases with the number of saccharide units in the SAMs, in agreement with both previous findings on saccharides and what is observed for strongly hydrated surfaces in general; i.e. that thicker hydrated layers provide higher barriers to protein adsorption. Contrary to observations in fouling assays on other oligosaccharide-terminated SAMs, as well as published results on other types of surfaces, settlement of Ulva spores followed an opposite trend to that of protein adsorption, in that settlement was higher on bulkier, and more hydrated saccharide SAM moieties. The lactose-based SAMs used in this study have the inclination of forming more ordered layers for the larger saccharide units, and we speculate that the degree of order in the SAMs, and associated differences in crystallinity or stiffness, is in this case an important parameter for the attachment of these organisms. This is supported by the removal assays, where qualitative agreement is found with previous studies relating the adhesion strength to molecular order and crystallinity (Bowen et al. 2007). Further work on both SAM characterization (for example friction force measurements to study surface lubricity and interfacial friction, or conformational changes under different conditions) and fouling assays on SAMs with wellknown surface mechanical and physicochemical properties, are needed to verify this. This study also corroborates our previous conclusion that wettability can be inadequate for quantitative predictions of the attachment of marine organisms (Ederth et al. 2011, Petrone et al. 2011). This paper has highlighted molecular order/disorder as a parameter of importance for understanding 
settlement and adhesion of marine organisms. However, further work is needed to establish this correlation and its possible impact on future development of antifouling coatings.

\section{Acknowledgements}

This study was supported from the European Community's Seventh Framework Programme FP7/2007-2013 under Grant Agreement number [237997] (SEACOAT). TE acknowledges financial support from the Swedish Government Strategic Research Area in Materials Science on Functional Materials at Linköping University (Faculty Grant SFO-Mat-LiU \# 2009-00971). JF acknowledges ONR (USA) award N0001-08-1-0010. 


\section{References}

Aripin NFK, Park JW, Park HJ. 2012. Preparation of vesicle drug carrier from palm oil- and palm kernel oil-based glycosides. Colloids Surf, B. 6/15/;95:144-153.

Bennett SM, Finlay JA, Gunari N, Wells DD, Meyer AE, Walker GC, Callow ME, Callow JA, Bright FV, Detty MR. 2009. The role of surface energy and water wettability in aminoalkyl/fluorocarbon/hydrocarbon-modified xerogel surfaces in the control of marine biofouling. Biofouling. 2010/02/01;26:235-246.

Bowen J, Pettitt ME, Kendall K, Leggett GJ, Preece JA, Callow ME, Callow JA. 2007. The influence of surface lubricity on the adhesion of Navicula perminuta and Ulva linza to alkanethiol self-assembled monolayers. J R Soc Interface. Jun 22;4:473-477.

Callow J, Callow M. 2006. The Ulva Spore Adhesive System. In: Biological Adhesives. Springer Berlin Heidelberg. p. 63-78.

Callow JA, Callow ME. 2011. Trends in the development of environmentally friendly foulingresistant marine coatings. Nat Commun. 03/22/online;2:244.

Callow ME, Callow JA, Ista LK, Coleman SE, Nolasco AC, Lopez G. 2000. Use of SelfAssembled Monolayers of Different Wettabilities To Study Surface Selection and Primary Adhesion Processes of Green Algal (Enteromorpha) Zoospores. Appl Environ Microbiol.66:6.

Callow ME, Callow JA, Pickett-Heaps JD, Wetherbee R. 1997. Primary adhesion of Enteromorpha (Chlorophyta, Ulvales) propagules: Quantitative settlement studies and video microscopy. J Phycol.33:938-947.

Callow ME, Jennings AR, Brennan AB, Seegert CE, Gibson A, Wilson L, Feinberg A, Baney R, Callow JA. 2002. Microtopographic Cues for Settlement of Zoospores of the Green Fouling Alga Enteromorpha. Biofouling. 2002/01/01;18:229-236.

Cao X, Pettit ME, Conlan SL, Wagner W, Ho AD, Clare AS, Callow JA, Callow ME, Grunze M, Rosenhahn A. 2009. Resistance of Polysaccharide Coatings to Proteins, Hematopoietic Cells, and Marine Organisms. Biomacromolecules. 2009/04/13;10:907-915.

Du Q, Freysz E, Shen YR. 1994. Vibrational spectra of water molecules at quartz/water interfaces. Phys Rev Lett.72:238.

Ederth T, Ekblad T, Pettitt ME, Conlan SL, Du CX, Callow ME, Callow JA, Mutton R, Clare AS, D'Souza F, et al. 2011. Resistance of galactoside-terminated alkanethiol selfassembled monolayers to marine fouling organisms. ACS Appl Mater Interfaces. Oct;3:3890-3901.

Ekblad T, Bergström G, Ederth T, Conlan SL, Mutton R, Clare AS, Wang S, Liu Y, Zhao Q, D'Souza F, et al. 2008. Poly(ethylene glycol)-Containing Hydrogel Surfaces for Antifouling Applications in Marine and Freshwater Environments. Biomacromolecules. 2008/10/13;9:2775-2783.

Finlay JA, Bennett SM, Brewer LH, Sokolova A, Clay G, Gunari N, Meyer AE, Walker GC, Wendt DE, Callow ME, et al. 2010. Barnacle settlement and the adhesion of protein and diatom microfouling to xerogel films with varying surface energy and water wettability. Biofouling. Aug;26:657-666.

Finlay JA, Callow ME, Schultz MP, Swain GW, Callow JA. 2002. Adhesion Strength of Settled Spores of the Green Alga Enteromorpha. Biofouling.18:251-256. 
Finlay JA, Schultz MP, Cone G, Callow ME, Callow JA. 2013. A novel biofilm channel for evaluating the adhesion of diatoms to non-biocidal coatings. Biofouling. 2013/04/01;29:401-411.

Flemming H-C, Wingender J. 2001. Relevance of microbial extracellular polymeric substances (EPSs) - Part I: Structural and ecological aspects Water Science \& Technology.43:8.

Fyrner T, Ederth T, Aili D, Liedberg B, Konradsson P. 2013. Synthesis of oligo(lactose)-based thiols and their self-assembly onto gold surfaces. Colloids and surfaces B, Biointerfaces. May 1;105:187-193.

Fyrner T, Lee HH, Mangone A, Ekblad T, Pettitt ME, Callow ME, Callow JA, Conlan SL, Mutton R, Clare AS, et al. 2011. Saccharide-functionalized alkanethiols for foulingresistant self-assembled monolayers: synthesis, monolayer properties, and antifouling behavior. Langmuir. Dec 20;27:15034-15047.

Ham HO, Park SH, Kurutz JW, Szleifer IG, Messersmith PB. 2013. Antifouling GlycocalyxMimetic Peptoids. J Am Chem Soc. 2013/09/04;135:13015-13022.

Harder P, Grunze M, Dahint R, Whitesides GM, Laibinis PE. 1998. Molecular Conformation in Oligo(ethylene glycol)-Terminated Self-Assembled Monolayers on Gold and Silver Surfaces Determines Their Ability To Resist Protein Adsorption. J Phys Chem B. 1998/01/01;102:426-436.

Hederos M, Konradsson P, Liedberg B. 2005. Synthesis and Self-Assembly of GalactoseTerminated Alkanethiols and Their Ability to Resist Proteins. Langmuir. 2005/03/01;21:2971-2980.

Herrwerth S, Eck W, Reinhardt S, Grunze M. 2003. Factors that Determine the Protein Resistance of Oligoether Self-Assembled Monolayers - Internal Hydrophilicity, Terminal Hydrophilicity, and Lateral Packing Density. J Am Chem Soc. 2003/08/01;125:9359-9366.

Hower JC, Bernards MT, Chen S, Tsao H-K, Sheng Y-J, Jiang S. 2008. Hydration of “Nonfouling” Functional Groups. J Phys Chem B. 2009/01/08;113:197-201.

Ista LK, López GP. 2012. Interfacial Tension Analysis of Oligo(ethylene glycol)-Terminated Self-Assembled Monolayers and Their Resistance to Bacterial Attachment. Langmuir. 2012/09/04;28:12844-12850.

Jeon SI, Lee JH, Andrade JD, De Gennes PG. 1991. Protein-surface interactions in the presence of polyethylene oxide: I. Simplified theory. J Colloid Interface Sci. 3/1/;142:149158.

Kim J, Cremer PS. 2000. IR-Visible SFG Investigations of Interfacial Water Structure upon Polyelectrolyte Adsorption at the Solid/Liquid Interface. J Am Chem Soc.122:1237112372.

Luk Y-Y, Kato M, Mrksich M. 2000. Self-Assembled Monolayers of Alkanethiolates Presenting Mannitol Groups Are Inert to Protein Adsorption and Cell Attachment. Langmuir. 2000/11/01;16:9604-9608.

Molino PJ, Wetherbee R. 2008. The biology of biofouling diatoms and their role in the development of microbial slimes. Biofouling. 2008/07/04;24:365-379.

Morra M, Cassineli C. 1999. Non-fouling properties of polysaccharide-coated surfaces. J Biomater Sci, Polym Ed. 1999/01/01;10:1107-1124.

Pasche S, De Paul SM, Vörös J, Spencer ND, Textor M. 2003. Poly(1-lysine)-graftpoly(ethylene glycol) Assembled Monolayers on Niobium Oxide Surfaces: A Quantitative 
Study of the Influence of Polymer Interfacial Architecture on Resistance to Protein Adsorption by ToF-SIMS and in Situ OWLS. Langmuir. 2003/10/01;19:9216-9225.

Petrone L, Di Fino A, Aldred N, Sukkaew P, Ederth T, Clare AS, Liedberg B. 2011. Effects of surface charge and Gibbs surface energy on the settlement behaviour of barnacle cyprids (Balanus amphitrite). Biofouling. 2011/10/15;27:1043-1055.

Piehler J, Brecht A, Hehl K, Gauglitz G. 1999. Protein interactions in covalently attached dextran layers. Colloids Surf, B. 7//;13:325-336.

Porter MD, Bright TB, Allara DL, Chidsey CED. 1987. Spontaneously organized molecular assemblies. 4. Structural characterization of n-alkyl thiol monolayers on gold by optical ellipsometry, infrared spectroscopy, and electrochemistry. J Am Chem Soc. 1987/06/01;109:3559-3568.

Poulsen N, Kröger N, Harrington MJ, Brunner E, Paasch S, Buhmann MT. 2014. Isolation and biochemical characterization of underwater adhesives from diatoms. Biofouling. 2014/04/21;30:513-523.

Prime KL, Whitesides GM. 1993. Adsorption of proteins onto surfaces containing end-attached oligo(ethylene oxide): a model system using self-assembled monolayers. J Am Chem Soc. 1993/11/01;115:10714-10721.

Riepl M, Östblom M, Lundström I, Svensson SCT, Denier van der Gon AW, Schäferling M, Liedberg B. 2005. Molecular Gradients: An Efficient Approach for Optimizing the Surface Properties of Biomaterials and Biochips. Langmuir. 2005/02/01;21:1042-1050.

Ruegsegger MA, Marchant RE. 2001. Reduced protein adsorption and platelet adhesion by controlled variation of oligomaltose surfactant polymer coatings. J Biomed Mater Res.56:159-167.

Schilp S, Kueller A, Rosenhahn A, Grunze M, Pettitt ME, Callow ME, Callow JA. 2007. Settlement and adhesion of algal cells to hexa(ethylene glycol)-containing self-assembled monolayers with systematically changed wetting properties. Biointerphases. Dec;2:143150 .

Schilp S, Rosenhahn A, Pettitt ME, Bowen J, Callow ME, Callow JA, Grunze M. 2009. Physicochemical properties of (ethylene glycol)-containing self-assembled monolayers relevant for protein and algal cell resistance. Langmuir. Sep 1;25:10077-10082.

Schultz MP, Finlay JA, Callow ME, Callow JA. 2000. A turbulent channel flow apparatus for the determination of the adhesion strength of microfouling organisms. Biofouling. 2000/09/01;15:243-251.

Schultz MP, Finlay JA, Callow ME, Callow JA. 2003. Three Models to Relate Detachment of Low Form Fouling at Laboratory and Ship Scale. Biofouling. 2003/01/01;19:17-26.

Sen Gupta A, Wang S, Link E, Anderson EH, Hofmann C, Lewandowski J, Kottke-Marchant K, Marchant RE. 2006. Glycocalyx-mimetic dextran-modified poly(vinyl amine) surfactant coating reduces platelet adhesion on medical-grade polycarbonate surface. Biomaterials. 6//;27:3084-3095.

Thome I, Pettitt ME, Callow ME, Callow JA, Grunze M, Rosenhahn A. 2012. Conditioning of surfaces by macromolecules and its implication for the settlement of zoospores of the green alga Ulva linza. Biofouling. 2012/05/01;28:501-510. 
Valiokas R, Svedhem S, Svensson SCT, Liedberg B. 1999. Self-Assembled Monolayers of Oligo(ethylene glycol)-Terminated and Amide Group Containing Alkanethiolates on Gold. Langmuir. 1999/05/01;15:3390-3394.

Valiokas R, Östblom M, Svedhem S, Svensson SCT, Liedberg B. 2000. Temperature-Driven Phase Transitions in Oligo(ethylene glycol)-terminated Self-Assembled Monolayers. J Phys Chem B. 2000/08/01;104:7565-7569.

Wang RLC, Kreuzer HJ, Grunze M. 2000. The interaction of oligo(ethylene oxide) with water: a quantum mechanical study. Phys Chem Chem Phys.2:3613-3622.

von Minden HM, Brandenburg K, Seydel U, Koch MHJ, Garamus V, Willumeit R, Vill V. 2000. Thermotropic and lyotropic properties of long chain alkyl glycopyranosides. Part II. Disaccharide headgroups. Chem Phys Lipids. 8//;106:157-179.

Zargiel KA, Coogan JS, Swain GW. 2011. Diatom community structure on commercially available ship hull coatings. Biofouling. 2011/10/15;27:955-965.

Zargiel KA, Swain GW. 2014. Static vs dynamic settlement and adhesion of diatoms to ship hull coatings. Biofouling. 2014/01/02;30:115-129. 


\section{Tables}

Table 1. Advancing $\left(\theta_{a}\right)$ and receding $\left(\theta_{r}\right)$ contact angles, and ellipsometric thicknesses $(d)$ of the used SAMs.

\begin{tabular}{|c|c|c|c|}
\hline \multirow{2}{*}{ SAM } & \multicolumn{2}{|c|}{ Contact angles } & Ellipsometric \\
\cline { 2 - 3 } & $\begin{array}{c}\theta_{a} \\
\text { (degrees) }\end{array}$ & $\begin{array}{c}\theta_{r} \\
\text { (degrees) }\end{array}$ & $\begin{array}{c}\text { (nm) } \\
\text { Lac1 }\end{array}$ \\
$<10$ & $<10$ & $15.0 \pm 0.8$ \\
\hline Lac2 & $<10$ & $<10$ & $19.4 \pm 0.6$ \\
\hline Lac3 & $<10$ & $<10$ & $29.1 \pm 0.5$ \\
\hline Mal-Tri & $<10$ & $<10$ & $30.6 \pm 0.3$ \\
\hline mOEG & $69 \pm 0$ & $61 \pm 4$ & $32.7 \pm 1.3$ \\
\hline
\end{tabular}

Table 2. Properties of the proteins used for the adsorption test.

\begin{tabular}{|c|c|c|c|}
\hline Protein & $\begin{array}{c}\text { Molecular } \\
\text { weight }(\mathrm{kDa})\end{array}$ & Isoelectric point & Net charge at $\mathrm{pH} 7.4^{*}$ \\
\hline \multirow{2}{*}{ Fib } & 340 & $\alpha 7.73$ & $\alpha+1.8$ \\
& & $\gamma 5.47$ & $\beta+5.8$ \\
& & 5.60 & $\gamma-14.8$ \\
\hline BSA & 66 & 11 & -18 \\
\hline Lys & 14.7 & 2.2 & +7.3 \\
\hline Pep & 35 & -38 \\
\hline
\end{tabular}

*Net charge was calculated using Protein Calculator v3.4, developed by Chris Putnam at the Scripps Research Institute (www.scripps.edu/ cdputnam/protcalc). 


\section{Figure captions}

Figure 1. Structure of the three lactose-based thiols (Lac1-3), the maltotrioside (Mal-tri), and the methylated oligo ethylene thiol (mOEG), used to form the SAMs.

Figure 2. Infrared reflection-absorption spectra in (a) the $\mathrm{O}-\mathrm{H}$ and $\mathrm{C}-\mathrm{H}-$-stretching regions, and (b) in the fingerprint region, for the used SAMs.

Figure 3. Protein adsorption on the SAMs. The surfaces were incubated in $1 \mathrm{mg} / \mathrm{mL}$ protein solutions and the corresponding thickness increases were determined by ellipsometry. Error bars represent the standard deviation of the mean of three sample replicates. The inset shows the result of three different fibrinogen adsorption assays.

Figure 4. Densities of settled spores of Ulva linza on SAMs before (pre-flow) and after (postflow) exposure to $52 \mathrm{~Pa}$ wall shear stress in a water channel. Percentages indicate the fraction of cells removed after exposure to shear stress, for the samples where a significant difference was observed between the pre- and post-flow data. Error bars represent $95 \%$ confidence limits of measurements from 90 counts on three replicates..

Figure 5. Attachment of cells of the diatom Navicula incerta, before (pre-flow) and after exposure to $32 \mathrm{~Pa}$ shear stress (post-flow) in a water channel. Percentages indicate the fraction of cells removed after exposure to shear stress. Error bars represent 95\% confidence limits of measurements from 90 counts on three replicates.

Figure 6. Integrated O-H-stretch intensity in the wave number range $3600-3020 \mathrm{~cm}^{-1}$ (dashed line, left ordinate, normalized to the value for Lac3) and the ellipsometric thickness (solid line, right ordinate). 
Figure 1

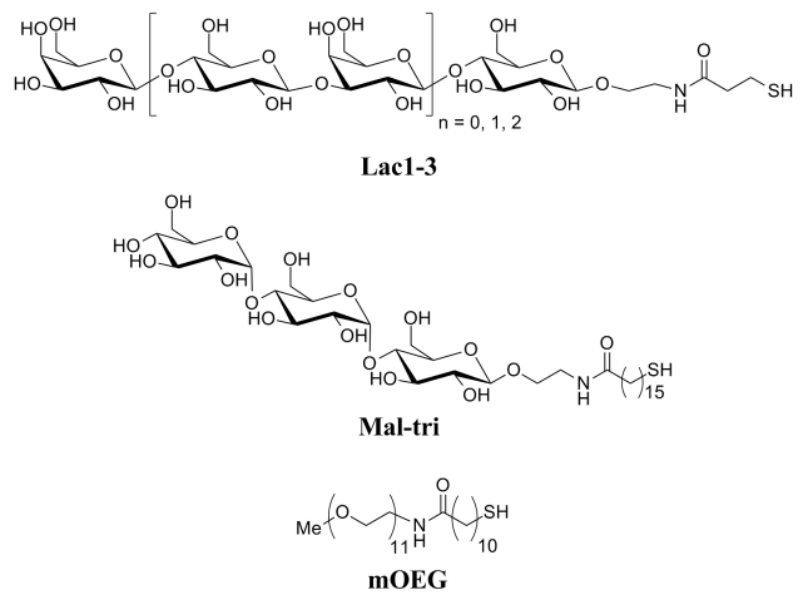




\section{Figure 2}
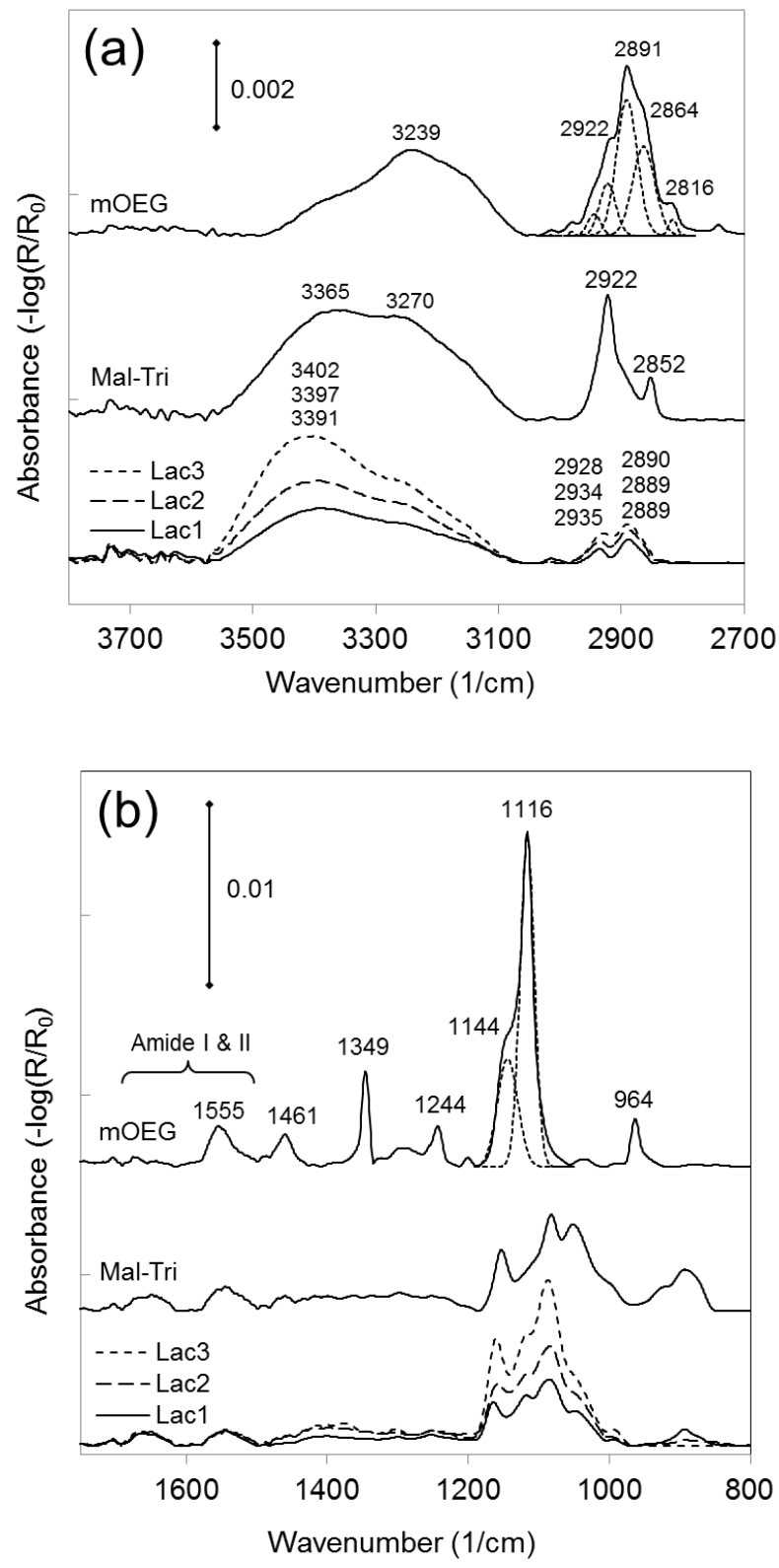
Figure 3

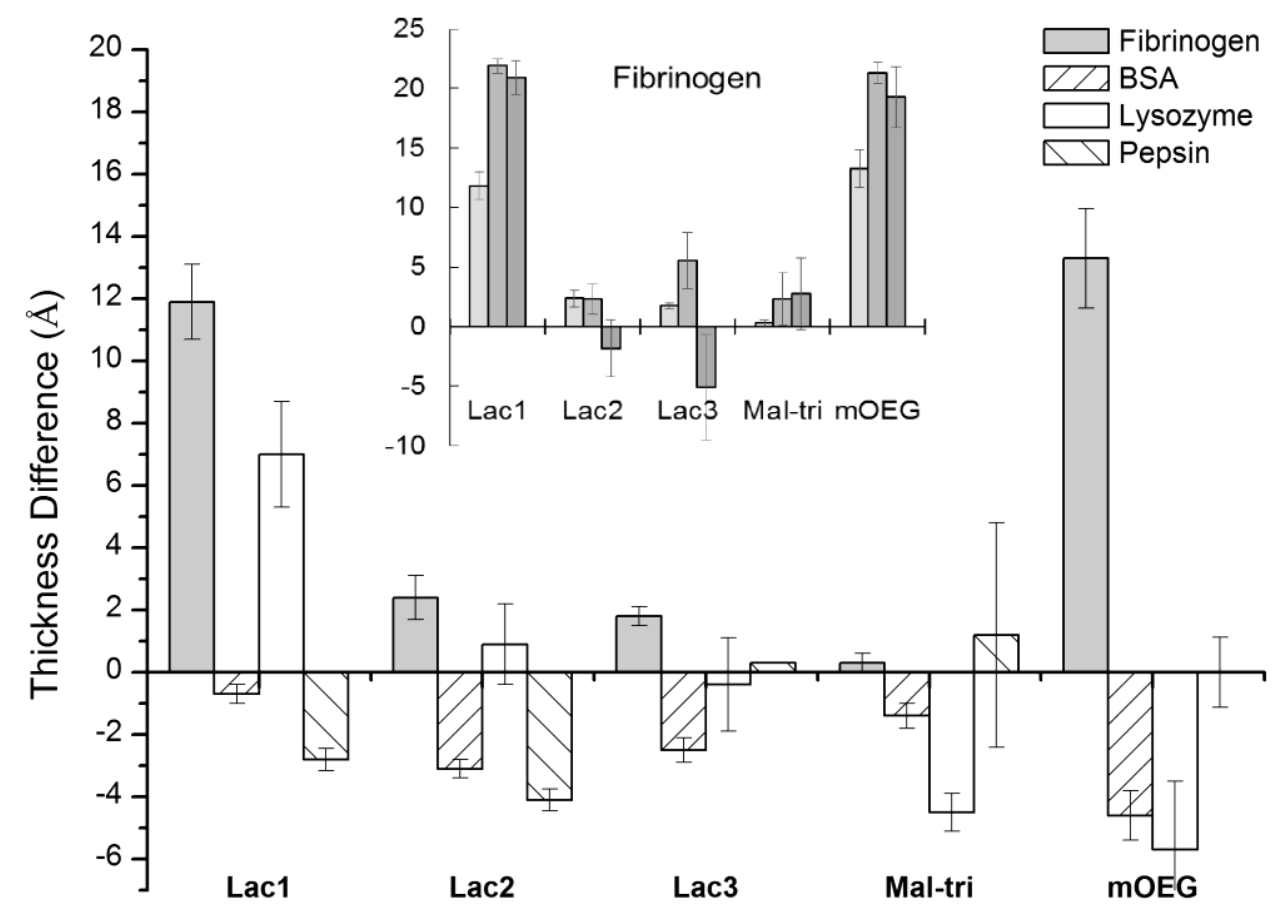


Figure 4

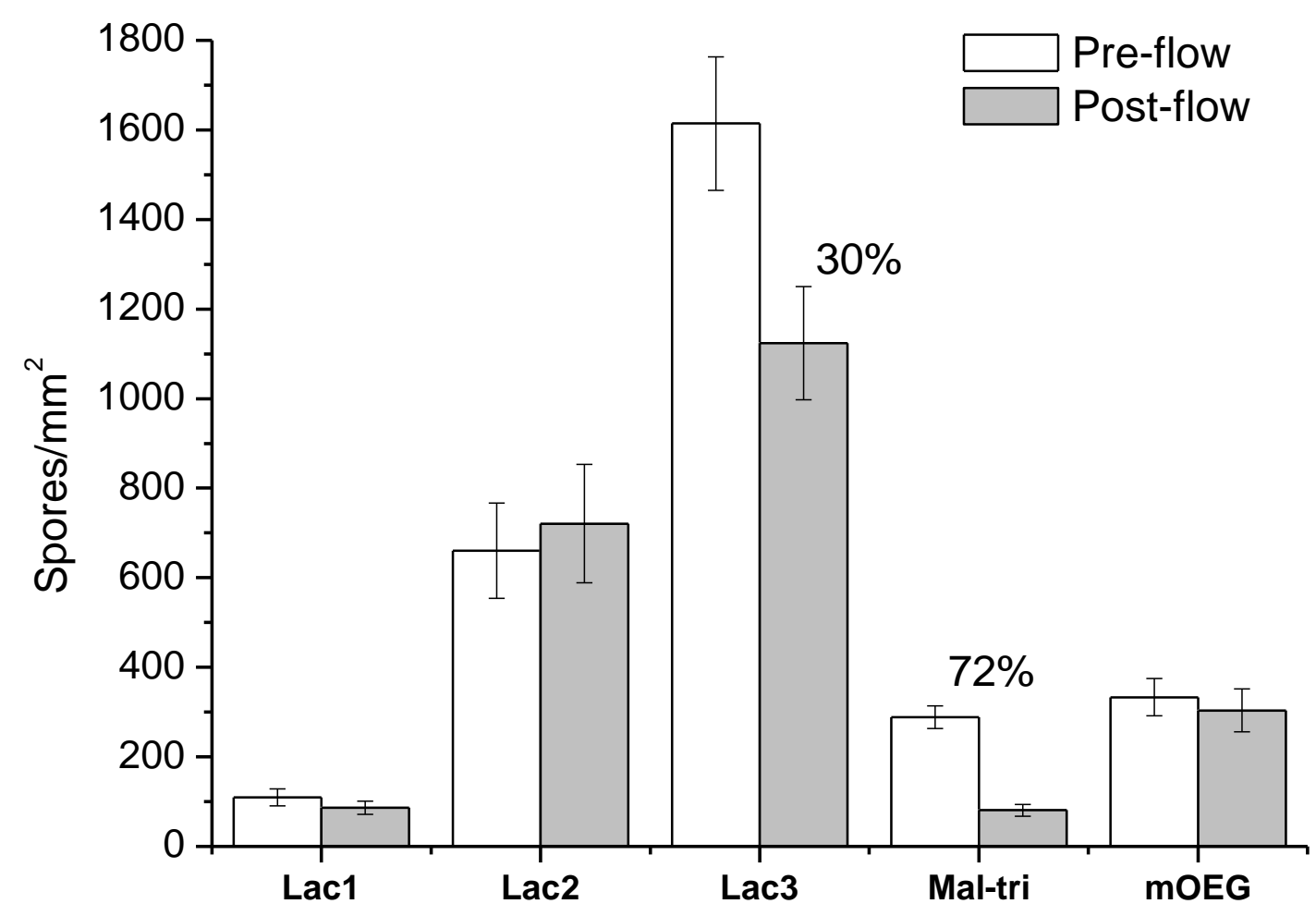


Figure 5

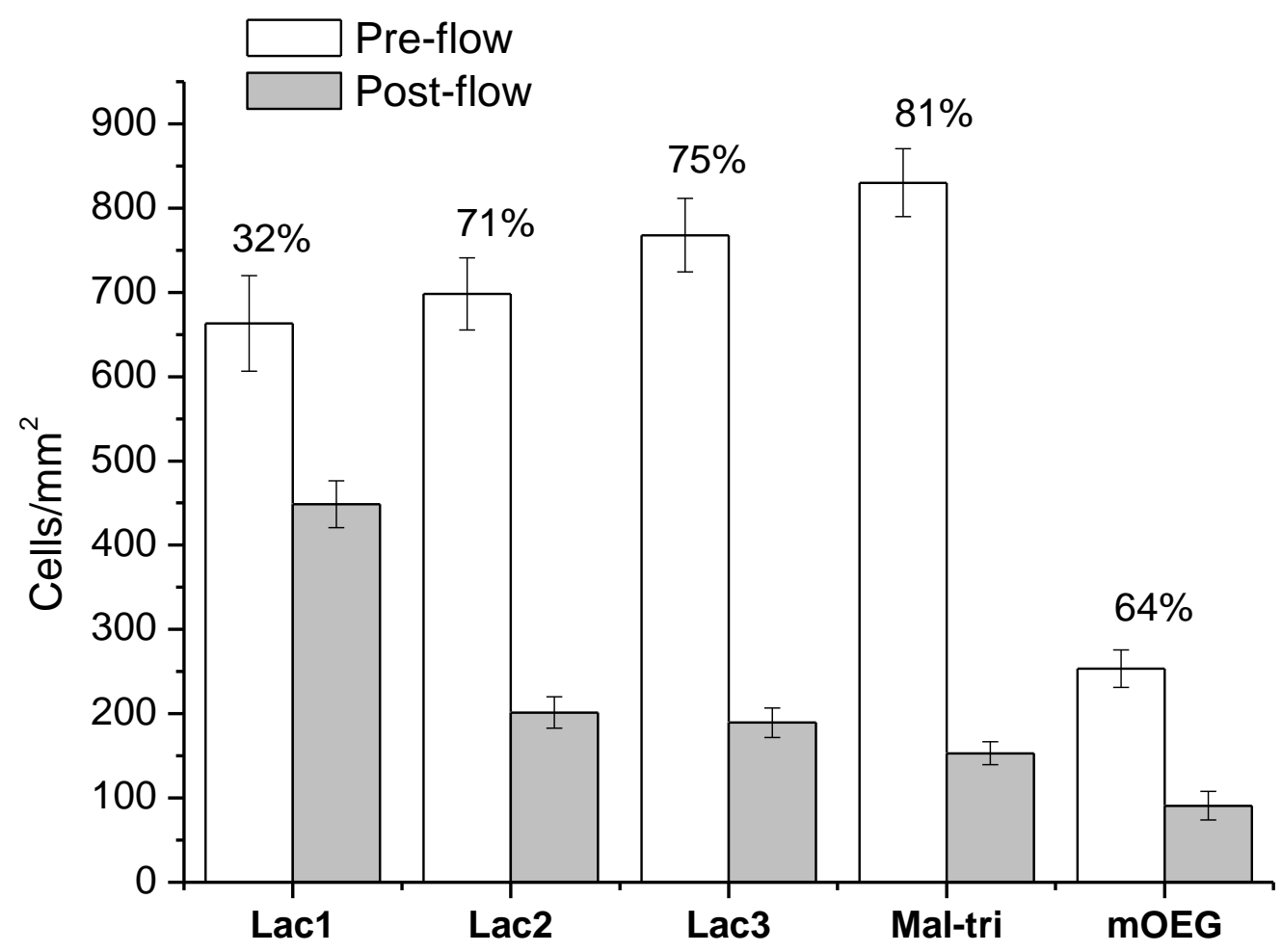


Figure 6

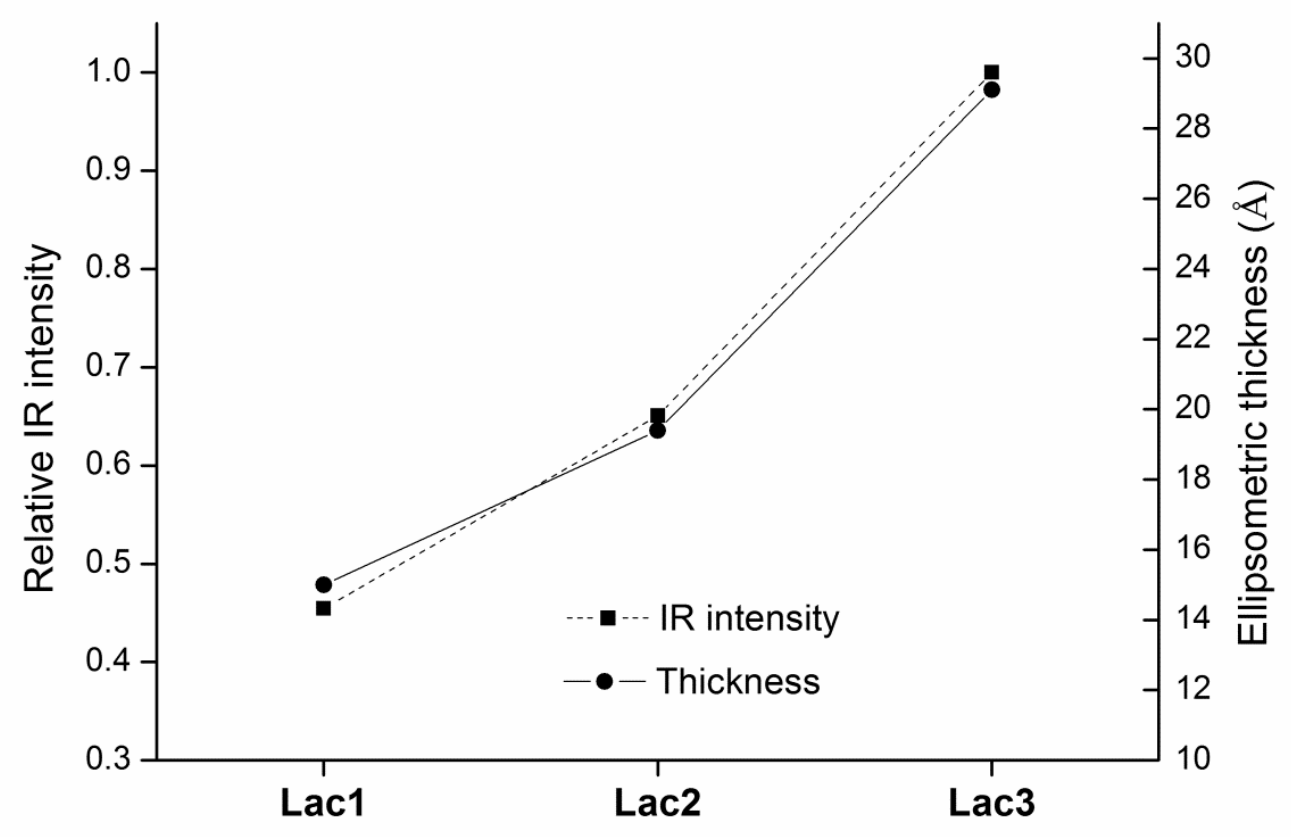

